\title{
Marker Assisted Selection for Mapping Population against Chickpea Wilt
}

\author{
Renuka Tatte $^{1 *}$, S. S. Mane ${ }^{1}$, Snehal Jukte ${ }^{1}$, Pravin Jadhav², \\ R. S. Nandanwar ${ }^{3}$ and A. N. Patil ${ }^{4}$ \\ ${ }^{1}$ Department of Plant Pathology, Post Graduate Institute, Akola, Maharashtra, India \\ ${ }^{2}$ Biotechnology Center, Post Graduate Institute, Akola, Maharashtra, India \\ ${ }^{3}$ Department of Agril. Botany, Post Graduate Institute, Akola, Maharashtra, India \\ ${ }^{4}$ AICRP on Pulses, Dr. Panjabrao Deshmukh Krishi Vidyapeeth, Krishinagar Po, \\ Akola (Ms) 444104, India \\ *Corresponding author
}

\begin{abstract}
A B S T R A C T
Marker assisted characterization of The 30 chickpea genotypes of chickpea $\mathrm{F}_{4}$ generation were selected for screening from three mapping population of different crosses (JG 62 (Susceptible) X ICCV 08113, PG 04154 (resistant) X JG 62 (susceptible) and PG 07101 (resistant) X JG 62 (susceptible). 10 genotypes from each population were selected for Fusarium wilt reaction was carried out using two molecular markers reported by earlier workers linked to disease resistant/susceptibility. In the present study, Allele Specific Associated Primer (ASAP) marker (namely, CS-27F/R ${ }_{700}$ ) linked to susceptibility and three Sequence Tagged Microsatellite site (STMS) marker (TA-59 ${ }_{258}$, TA- $96_{275}$, TR-19 ${ }_{227}$ ) linked to resistance allele were validated. The results indicates that ASAP (CS 27F/CS 27R) marker linked to susceptibility alleles and susceptibility is dominant over resistance. ASAP marker, (CS27F/R) screened on the 30 genotypes and gave no amplified product of 700 bp. in all 30 genotypes STMS marker, TA-59, TA-96 and TR-19 linked to resistance and produce amplification in resistant genotypes. The amplification sizes of TA-59, TA-96 and TR-19 as characterized in Cicer sp. were 258, 275 and 227 bp, respectively. Amplification was observed in all 30 genotype.
\end{abstract}

Keywords

Chickpea, Fusarium wilt, Molecular markers, Resistance, Susceptible

Article Info

Accepted:

20 May 2018

Available Online:

10 June 2018

\section{Introduction}

Chickpea, a self-pollinating diploid $(2 \mathrm{n}=16)$ species with a genome size of $740 \mathrm{Mbp}$, is the world's third most important food legume (Arumuganathan and Earle, 1991) It is a deep rooted crop belonging to the family Leguminosae. It is commonly known as channa, gram, garbanzo bean etc. It is originated in south-eastern Turkey around
7,500 from where it has spread to other countries of the world. India ranks first in the production and productivity of chickpea during 2015-16 covering $8.87 \mathrm{M}$. ha. and production $7.17 \mathrm{Mt}$ ) (Source: agricoop.nic.in) Fusarium wilt caused by a Deuteromycetes fungus Fusarium oxysporum Schlechtend. f. sp. ciceris (Padwick) Mauto and K. Sato, is the most destructive disease of chickpea and is wide-spread in chickpea growing areas of Asia, Africa, Southern Europe, Peru, Syria, 
Ethiopia, Mexico, Spain, Tunisia, Turkey, USA and the countries of the USSR (Westerlund et al., 1974). Annual yield losses due to wilt have been estimated at $10-15 \%$ (Jalali and Chand 1992), but it is capable of causing $100 \%$ loss under favorable conditions (Halila and Strange, 1996). The fungus is a soil borne which lives in seeds and dead plant materials in the form of chalmydospore. The wilted seedlings shows a dull green color of the foliage; sudden drooping of the petioles, rachis and leaves. The plants, when uprooted, showed uneven shrinkage at the collar (Nene et al., 1987). Nowadays, application of chemical pesticides is limited because of hazards environmental pollutions and health risks. So, using genetic resistance and cultivating resistant genotypes is the most suitable and practical method for management of Fusarium wilt of chickpea.

The phenotypically selection of the resistant genotypes is the time consuming and complicated. So, using DNA based molecular marker is a major tool for the selection of the resistant cultivars; facilitating the process (Lindhout, 2002; Tanksley et al., 1992). The selection and inheritance of the desirable traits is now become possible with the advancement of Marker Assisted Selection (MAS) which provides a beneficial source to exploit the potentiality of genes against agronomic traits (Choudhary, 2010; Allahverdipoor KH, 2011). Marker assisted selection (MAS) using DNA markers tightly linked to wilt resistance genes can be used to screen a large number of germplasm lines for the presence of these genes without actually subjecting them to the pathogen and to pyramid them into agronomical superior varieties. MAS are an accurate, easy as compared to conventional method, less time consuming and independent to environmental conditions (Padliya R.V., 2013). The present study was under taken with an objective to Assessment of parents and segregating population by using Allele
Specific Associated Primer (ASAP) markers and Sequence Tagged Microsatellite site (STMS) marker.

\section{Materials and Methods}

\section{Plant material}

The samples were collected from the field of Pulses Research unit, Dr. PDKV, Akola. The mapping population of $\mathrm{F}_{4}$ generation from crosses of JG 62 (susceptible) X ICCV 08311 (resistant), ICCV 04514 (resistant) X JG 62 (susceptible) and PG 07101 (resistant) X JG 62 (susceptible). 10 genotypes from each population were selected. Parents used for crossing were ICCV 08311, ICCV 04514, PG 07101 and JG-62.All genotypes were sown in plastic pots and leaf samples were taken.

\section{DNA isolation}

Total genomic DNA was isolated from the young leaves following the CTAB method. The DNA obtained after extraction was confirmed by running it on $0.8 \%$ agarose gel (containing ethidium bromide @ $0.5 \mathrm{mg} / \mathrm{ml}$ ) in a horizontal gel electrophoresis system.

\section{PCR amplification and electrophoresis}

The PCR was carried out in small reaction tubes, containing a reaction volume typically of $20 \mu \mathrm{l}$ that was inserted into a thermal cycle (Eppendorf) that heated and cooled the reaction tubes within it to the precise temperature required for each step of the reaction. PCRs were run on the programmable thermal cycle $94^{\circ} \mathrm{C}$ Denaturation, $50^{\circ} \mathrm{C}$ Annealing, $\quad 72^{\circ} \mathrm{C}$ Extension. Annealing temperature varied from primer to primer. Electrophoresis of ASAP and STMS-PCR amplified analysis on $1.5 \%$ agarose gel was carried out in 1x TBE buffer in horizontal gel electrophoresis

\section{Results and Discussion}


Marker assisted characterization of 30 chickpea genotypes differing for Fusarium wilt reaction was carried out using two molecular markers reported by earlier workers linked to disease resistant/ susceptibility. In the present study, Allele Specific Associated Primer (ASAP) marker (namely, CS-27F/ R $_{700}$ ) linked to susceptibility and three Sequence Tagged Microsatellite site (STMS) marker (TA-59 $9_{258}$, TA- $96_{275}$, TR-19 227 ) linked to resistance allele were validated. The molecular markers ASAP $\left(\mathrm{CS} 27 \mathrm{~F} / \mathrm{R}_{700}\right)$, and STMS $\left(\right.$ TA59 $9_{258}$, TA96 $_{275}$, TR19 227 ) amplified against 30 genotypes of chickpea F4 generation.

The ASAP (CS 27F/CS 27R) marker linked to susceptibility alleles and susceptibility is dominant over resistance. ASAP marker, (CS27F/R) screened on the 30 genotypes and gave no amplified product of $700 \mathrm{bp}$. in all 30 genotypes of cross I (JG $62 \mathrm{X}$ ICCV 08311), in cross II (ICCV 04514 X JG 62), In cross III (PG $07101 \mathrm{X} \mathrm{JG} \mathrm{62).} \mathrm{The} \mathrm{absence} \mathrm{of} \mathrm{marker}$ indicated resistance $\left(\mathrm{h}_{1} \mathrm{~h}_{1} \mathrm{~h}_{2} \mathrm{~h}_{2}\right)$ in all 30 genotypes

The STMS marker, TA-59, TA-96 and TR-19 linked to resistance and produce amplification in resistant genotypes. The amplification sizes of TA-59, TA-96 and TR-19 as characterized in Cicer sp. were 258, 275 and 227 bp, respectively.

Amplification was observed in all 30 genotype of cross I (JG 62 X ICCV 08311), in cross II (ICCV 04514 X JG 62), In cross III (PG 07101 X JG 62). Presence of marker indicated resistance in all 30 genotypes.

Table.1 List of primers used with their sequences

\begin{tabular}{|l|l|l|c|c|}
\hline $\begin{array}{l}\text { Sr. } \\
\text { No. }\end{array}$ & Primer & \multicolumn{1}{|c|}{ Primer sequence } & $\begin{array}{c}\text { Expected fragment } \\
\text { size (bp) }\end{array}$ & $\begin{array}{c}\text { Annealing } \\
\text { Temp. }\left({ }^{\circ} \mathbf{C}\right)\end{array}$ \\
\hline $\mathbf{1}$ & CS-27A & $\begin{array}{l}\text { F - AGC TGG TCG CGG GTC AGA } \\
\text { GGA AGA } \\
\text { R - AGT GGT CGC GAT GGG GCC } \\
\text { ATG GTG }\end{array}$ & 700 & 63.4 \\
\hline $\mathbf{2}$ & TA-59 & $\begin{array}{l}\text { F - ATC TAA AGA GAA ATC AAA ATT } \\
\text { GTC GAA } \\
\text { R - GCA AAT GTG AAG CAT GTA TAG } \\
\text { ATA AAG }\end{array}$ & 258 & 48.8 \\
\hline $\mathbf{3}$ & TA-96 & $\begin{array}{l}\text { F-TGT TTT GGA GAA GAG TGA TTC } \\
\text { R- TGT GCA TGC AAA TTC TTA CT }\end{array}$ & 275 & 49 \\
\hline $\mathbf{4}$ & TR-19 & $\begin{array}{l}\text { F - TCA GTA TCA CGT GTA ATT CGT } \\
\text { R- CAT GAA CAT CAA GTT CTC CA }\end{array}$ & 227 & 49 \\
\hline
\end{tabular}

Table.2 Reaction of different parents of $\mathrm{F}_{4}$ generation with STMS (TA59) Marker

\begin{tabular}{|l|c|c|}
\hline \multicolumn{1}{|c|}{ Genotypes } & STMS (TA59) banding pattern & Wilt Reaction \\
\hline JG-62 & Absent & Susceptible (Early wilt) \\
\hline ICCV 08311 & Present & Resistant \\
\hline ICCV 04514 & Present & Resistant \\
\hline PG 07101 & Present & Resistant \\
\hline
\end{tabular}


Table.3 Reaction of different genotype of cross I (JG 62 X ICCV 08311), cross II (ICCV 04514 $\mathrm{X} \mathrm{JG}$ 62), cross III (PG $07101 \mathrm{X} \mathrm{JG}$ 62) of $\mathrm{F}_{4}$ generation with ASAP (CS27) Marker

\begin{tabular}{|c|c|c|}
\hline Genotypes & ASMS Marker (CS-27) Banding pattern & Wilt Reaction \\
\hline \multicolumn{3}{|c|}{ cross I (JG $62 \times$ ICCV 08311) } \\
\hline 1 & Absent & Resistant \\
\hline 2 & Absent & Resistant \\
\hline 3 & Absent & Resistant \\
\hline 4 & Absent & Resistant \\
\hline 5 & Absent & Resistant \\
\hline 6 & Absent & Resistant \\
\hline$\overline{7}$ & Absent & Resistant \\
\hline 8 & Absent & Resistant \\
\hline 9 & Absent & Resistant \\
\hline 10 & Absent & Resistant \\
\hline \multicolumn{3}{|c|}{ cross II (ICCV 04514 X JG 62) } \\
\hline 1 & Absent & Resistant \\
\hline$\overline{2}$ & Absent & Resistant \\
\hline 3 & Absent & Resistant \\
\hline 4 & Absent & Resistant \\
\hline 5 & Absent & Resistant \\
\hline 6 & Absent & Resistant \\
\hline 7 & Absent & Resistant \\
\hline 8 & Absent & Resistant \\
\hline 9 & Absent & Resistant \\
\hline 10 & Absent & Resistant \\
\hline \multicolumn{3}{|c|}{ cross III (PG 07101 X JG 62) } \\
\hline 1 & Absent & Resistant \\
\hline$\overline{2}$ & Absent & Resistant \\
\hline 3 & Absent & Resistant \\
\hline 4 & Absent & Resistant \\
\hline 5 & Absent & Resistant \\
\hline 6 & Absent & Resistant \\
\hline 7 & Absent & Resistant \\
\hline 8 & Absent & Resistant \\
\hline 9 & Absent & Resistant \\
\hline 10 & Absent & Resistant \\
\hline
\end{tabular}


Plate.1 STMS (TA-59) banding Patterns

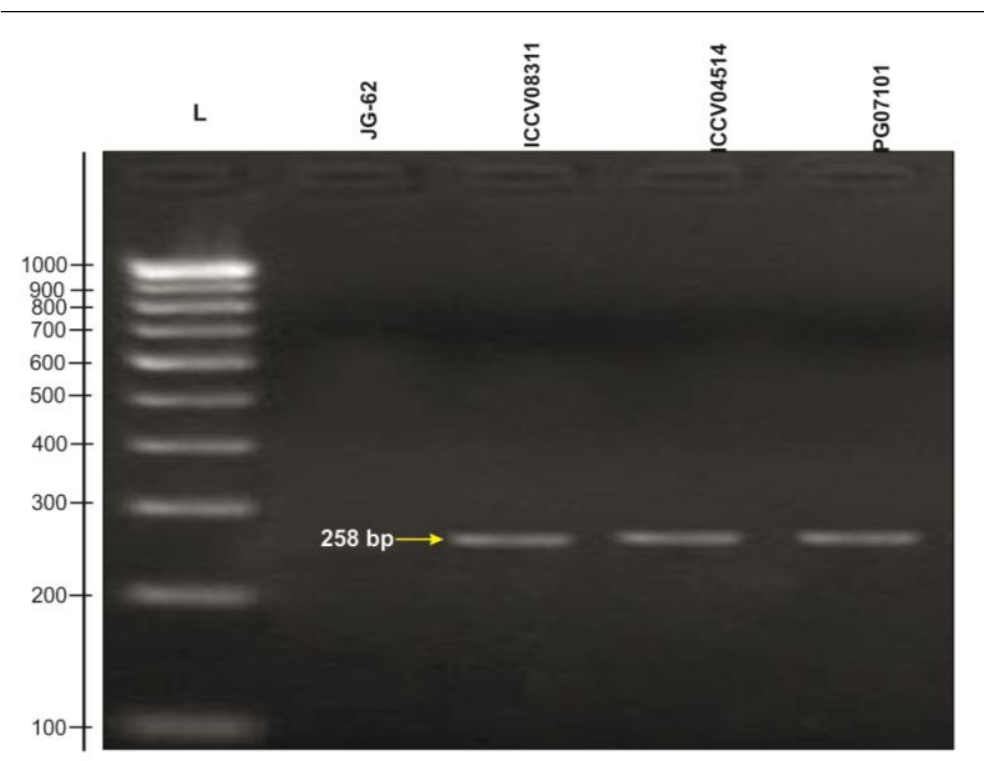

a) PCR amplification of DNA using TA59 primer in parent

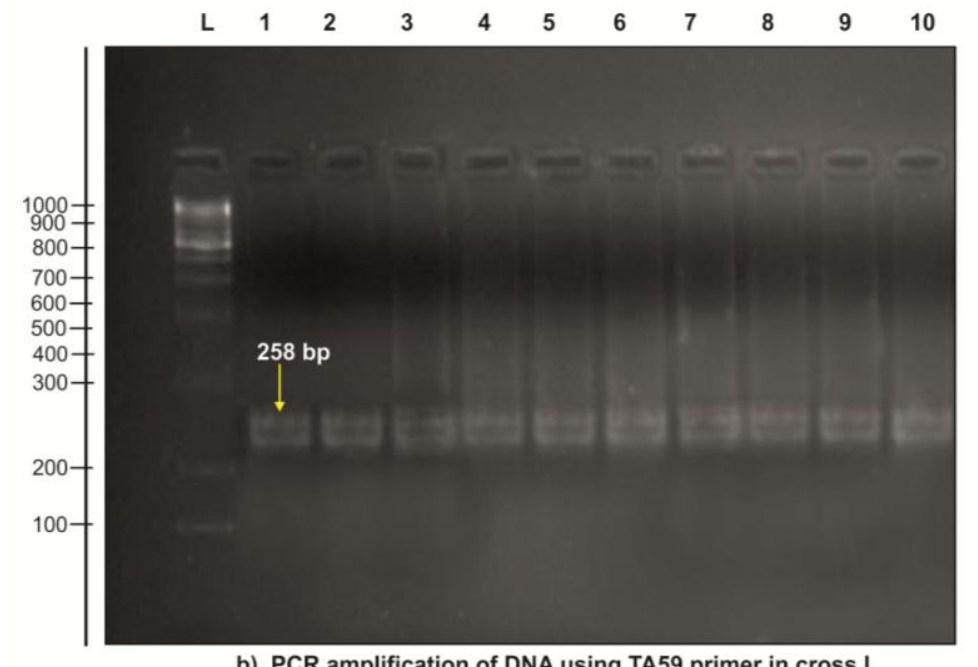

b) PCR amplification of DNA using TA59 primer in cross I

b) Cross I. JG 62 (susceptible) X ICCV 08311 (resistant)

The results indicates that ASAP (CS 27F/CS 27R) marker linked to susceptibility alleles and susceptibility is dominant over resistance. ASAP marker, (CS27F/R) screened on the 30 genotypes and gave no amplified product of $700 \mathrm{bp}$. in all 30 genotypes STMS marker, TA-59, TA-96 and TR-19 linked to resistance and produce amplification in resistant genotypes. The amplification sizes of TA-59, TA-96 and TR-19 as characterized in cicer sp. were 258, 275 and $227 \mathrm{bp}$, respectively.
Amplification was observed in all 30 genotype.

Genetics of wilt resistance against race 1 indicated three independent loci designated as $\mathrm{H}_{1}, \mathrm{H}_{2}$ and $\mathrm{H}_{3}$ govern resistance to wilt (Singh et. al. 1987). However some studies indicated two major independent loci, $\mathrm{H}_{1}$ and $\mathrm{H}_{2}$ determine resistance to race 1 in chickpea (Brinda and Ravikumar, 2005; Upadhyaya et. al. 1983). The dominant alleles at both $\mathrm{H}_{1}$ and 
$\mathrm{H}_{2}$ loci result in susceptible early wilting and recessive at any one $\left(\mathrm{h}_{1} \mathrm{~h}_{1} \mathrm{H}_{2}\right.$ or $\left.\mathrm{H}_{1} \mathrm{~h}_{2} \mathrm{~h}_{2}\right)$ produce susceptible late wilting and recessive at both the loci $\left(\mathrm{h}_{1} \mathrm{~h}_{1} \mathrm{~h}_{2} \mathrm{~h}_{2}\right)$ result in resistance. The first wilt resistance gene to be tagged in chickpea was $\mathrm{H}_{1}$ with $\mathrm{CS} \quad 27 \mathrm{~F} / \mathrm{CS} \quad 27 \mathrm{R}$ (ASAP) (Mayer et. al. 1997), which amplifies a fragment of $700 \mathrm{bp}$ linked to the allele for susceptibility. The ASAP marker CS-27F/R gave no amplified product of $700 \mathrm{bp}$, in cross I (JG 62 X ICCV 08311), in cross II (ICCV 04514 X JG 62), In cross III (PG 07101 X JG 62), absence of marker indicated resistant $\left(\mathrm{h}_{1} \mathrm{~h}_{1} \mathrm{~h}_{2} \mathrm{~h}_{2}\right) 30$ genotypes Mayer et al., (1997) was observed that ASAP marker CS-27F/R linked to disease resistance gave amplification of $700 \mathrm{bp}$ susceptible genotypes only. Three different STMS markers (TA-59, TA-96 and TR-19) linked to resistance allele by 3.8, 3.3 and $3.1 \mathrm{cM}$ distance respectively were expected amplification in resistant genotypes only. Winter et al., (1999) characterized and mapped 120 STMS on the chickpea genome map. The primer TA-59, TA-96 and TR-19 were mapped on same linkage group on which gene for disease resistance was present (Winter et al., 2000).Three STMS primer (TA-59, TA-96 and TR-19) were utilized in present study to characterize chickpea genotype for resistance. The PCR amplification of TA-59, TA-96, TR-19 primer generated two alleles, out of which the allele of $258 \mathrm{bp}, 275 \mathrm{bp}, 227 \mathrm{bp}$ was observed only in all resistant genotypes except JG62. Presence of marker indicated resistant all 30 genotypes. Winter et al., (1999) characterized and mapped STMS on the chickpea genome map. The primer TA-59, TA-96 and TR-19 were mapped on same linkage group on which gene for disease resistance was present (Winter et al., 2000).Soregaonet al., (2010) the primer pair cs-27F/ cs-27R, termed allele specific associated primer (ASAP) linked to the allele for susceptibility at $\mathrm{H}_{1}$ of susceptibility for fusarium wilt linked to $\mathrm{H}_{1}$ locus was absent in all other genotypes except JG 62 .
The screening of the chickpea genotypes causing wilt resistance genes can be facilitated with Marker Assisted Selection (MAS). The validated wilt linked markers could effectively be utilized in disease resistance breeding to enhance the selection strategy of parents and progeny. The phenotypic selection for the resistant gene can be done only in homozygous condition, because of its recessive nature, but using molecular markers, it can be identified in heterozygous condition also.

\section{References}

Aggarwal H, Alka Rao, A. Kumar, J. Singh, J. S. Rana, P. K. Naik, V. Chhokar, 2015. Assessment of genetic diversity among 125 cultivars of chickpea (Cicer arietinum L.) of Indian origin using ISSR markers. Turk J Bot., 39: 218-226.

Allahverdipoor, K. H., B. Bahramnejad and J. Amini, 2011. Selection of molecular markers associated with resistance to Fusarium wilt disease in chickpea (Cicer arientinum L.) using multivariate statistical techniques. Australian Journal of Plant Science. 5(13): 1801-1809.

Brinda, S. and R. L. Ravikumar, 2005. Inheritance of wilt resistance in Chickpea - A molecular marker analysis. Current Science, 88: 701702.

Choudhary, C.K. and Dinisha Abhishek, 2010. Inter - specific detection of polymorphism using sequence tagged microsatellites (STMS) in chickpea. Electronic Journal of Plant Breeding, 1(4): 484-488.

Halila, M. H. and R.N. Strange, 1996. Identification of the causal agent of wilt of chickpea in Tunisia as Fusarium oxysporum f. sp. ciceri race. Phytopathology. Mediterr., 35: 67-74.

Jalali M, L. Chand, 1992. Races of Fusarium oxysporum f. sp. ciceris. Plant Disease, 66: 809-810.

Lindhout P. 2002. The perspectives of polygenic resistance in breeding for durable disease resistance. Euphytica, 124: 217-226. 
Maisuria, H. Jekishandas, Patel, R. Mohanlal, Suthar, K. Parshottambhai 2017. Validation of Molecular Markers Linked to Fusarium Wilt Resistance in Chickpea Genotypes. Int. J. Pure App. Biosci., 5 (1): 254-260.

Mayer M.S., A. Tullu, C. J. Simon, J. Kumar, W. J. Kaiser, J. M. Kraft and F. J. Muehlbauer. 1997. Development of a DNA Marker for Fusarium Wilt Resistance in Chickpea. Crop Sci., 37 (5) 1625: 1629.

Nene, Y.L. and M.V. Reddy, 1987. Chickpea diseases and their control. CAB International, Oxon, United Kingdom.233-270.

Padaliya, R.V., K. P. Suthar, D. Singh, M.K. Mahatma and V. R. Patil, (2013). Marker assisted characterization of chickpea genotypes for wilt resistance. African Journal of Biotechnology, 12(50): 6907-6912.

Padwick, 1941. Report of Imperial Mycologist Sci. Rep. Agric. Res. Inst. New Delhi. 94 107.

Ratnaparkhe M. B., D. K. Santra, A. Tullu and F. J. Muehlbauer, 1998. Inheritance of intersimple-sequence-repeat polymorphisms and linkage with a Fusarium wilt resistance gene in chickpea. Theor Appl Genet., 96: 348-353.

Ravikumar R.L., B. S. Patil, C. D. Soregaon and S. G. Hegde, 2007. Genetic evidence for gametophytic selection of wilt resistant alleles in chickpea. Theor Appl Genet., 114: 619625

Singh H., J. Kumar, M. P. Haware and J. B Smithson, 1987. Genetics of resistance of Fusarium wilt in chickpeas. In: day PR. Jellies GJ (eds) Genetics and plant pathogenesis. Blackwell, oxford, CAB International Willingford UK., 339-342.

Soregaon C. D, D. Satish, D. G Kumar, R. L. Shinde and Ravikumar, 2010. Segregation of Fusarium Wilt Susceptibility Linked Dna Marker In Susceptible Resistance Cross Of Chickpea. Karnataka J. Agric. Sci., 23 (2): 320-321.
Soregaon. C. D. and R.L. Ravikumar, 2012. Marker assisted characterization of wilt resistance in productive chickpea genotypes. Electronic J. of Plant Breeding, 1(4): 11591163.

Tanksley S. D., M. W. Ganal, J. P. Prince, de Vicente, M. W. Bonierbale, P. Broun, T. M. Fulton, J. J. Giovannoni, S. Martin, G. B. Messeguer, R. J. Miller, A. H. Paterson, O. Pineda, Ro MS, R. A. Wing, W. Wu, N. D. Young, 1992. High density molecular linkage maps of the tomato and potato genomes. Genetics, 132: 1141-1160.

Upadhyaya, H. D., Smithson, J.B., Haware, M. P. and J. Kumar, 1983. Resistance to wilt in chickpea II. Further evidence for two genes for resistance to race 1. Euphytica, 32: 749755.

Westerland, F. V., R. N. Cambell and K. A. Kimble, 1974. Fungal root rots and wilt of chickpea in California. Phytopathology, 64 (4): 432-436.

Winter P, T. Pfaff, S. M. Udupa, B. Huttel, P. C. Sharma, S. Sahi, R. Arreguin-Espinoza, F Weigand, F. J. Muehlbauer, G. Kahl, (1999). Characterization and mapping of sequencetagged microsatellite sites in the chickpea (Cicer arietinum L.) genome. Mol. Gen. Genet., 262: 90-101.

Winter, P., A. M. Benko-Iseppon, B. Huttel, M. Ratnaparkhe, A. Tullu, G. Sonnante, 2000. A linkage map of the chickpea (Cicer arietinum L.) genome based on recombinant inbred lines from a $C$. arietinum $\times C$. reticulatm cross: localization of resistance genes for Fusarium wilt races 4 and 5. Theoretical and Applied Genetics, 101: 1155-1163.

Zakia Ahmad, A. S. Mumtaz, A. Ghafoor, A. Ali and M. Nisar, 2014. Marker Assisted Selection (MAS) for chickpea Fusarium oxysporum wilt resistant genotypes using PCR based molecular markers Mol. Biol. Rep., 41(10): 6755-6762.

\section{How to cite this article:}

Renuka Tatte, S. S. Mane, Snehal Jukte, Pravin Jadhav, R. S. Nandanwar and Patil A. N. 2018. Marker Assisted Selection for Mapping Population against Chickpea Wilt. Int.J.Curr.Microbiol.App.Sci. 7(06): 2480-2486. doi: https://doi.org/10.20546/ijcmas.2018.706.294 